(c) Copyright 2012 American Meteorological Society (AMS). Permission to use figures, tables, and brief excerpts from this work in scientific and educational works is hereby granted provided that the source is acknowledged. Any use of material in this work that is determined to be "fair use" under Section 107 of the U.S. Copyright Act September 2010 Page 2 or that satisfies the conditions specified in Section 108 of the U.S. Copyright Act (17 USC §108, as revised by P.L. 94-553) does not require the AMS's permission. Republication, systematic reproduction, posting in electronic form, such as on a web site or in a searchable database, or other uses of this material, except as exempted by the above statement, requires written permission or a license from the AMS. Additional details are provided in the AMS Copyright Policy, available on the AMS Web site located at (http://www.ametsoc.org/) or from the AMS at 617-227-2425 or copyrights@ametsoc.org. 


\title{
Interdisciplinary Climate: The Case of the First 50 Years of British Observations in Australia
}

\author{
Kendal McGuffie And Ann Henderson-SEllers \\ School of Physics and Advanced Materials, University of Technology Sydney, and Department of Environment and Geography, \\ Macquarie University, Sydney, New South Wales, Australia
}

(Manuscript received 25 January 2012, in final form 12 June 2012)

\begin{abstract}
This paper presents the case for improved interdisciplinarity in climate research in the context of assessing and discussing the caution required when utilizing some types of historical climate data. This is done by a case study examining the reliability of the instruments used for collecting weather data in Australia between 1788 and 1840, as well as the observers themselves, during the British settlement of New South Wales. This period is challenging because the instruments were not uniformly calibrated and were created, repaired, and used by a wide variety of people with skills that frequently remain undocumented. Continuing significant efforts to rescue such early instrumental records of climate are likely to be enhanced by more open, interdisciplinary research that encourages discussion of an apparent dichotomy of view about the quantitative value of early single-instrument data between historians of physics (including museum curators) and climate researchers.
\end{abstract}

\section{Interdisciplinary climate}

\section{a. Overview}

The study of climate is frequently claimed to be "interdisciplinary" (Schmidt and Moyer 2008): a characteristic seen as recent and not always advantageous (Averyt 2010). The exhortations to climate researchers to embrace the ever-broadening knowledge pool can be strident, with perceived failure to do so blamed for many ills including poor communication of science to the public (Pidgeon and Fischhoff 2011) and even stalled progress in climate understanding itself (Hamilton 2010). In climate research, "interdisciplinary ventures have led to both rapid growth in insight and near-catastrophic blunders" (McGuffie and Henderson-Sellers 2005, p. 66) while its traditional underpinning disciplines are said to carry "a hubris that they seemingly cannot shake off" (Hulme 2011, p. 178).

This research concerns the use of instrumental weather records from the late eighteenth and very early nineteenth centuries. Specifically, we examine the case of climatically relevant measurements made by the British in Australia from 1788 to 1840. Despite many excellent

Corresponding author address: A. Henderson-Sellers, Department of Environment and Geography, Macquarie University, Sydney, NSW 2109, Australia.

E-mail: ann.henderson-sellers@mq.edu.au efforts to rescue and analyze weather recordings of this vintage, the opinion of some museum curators and historians of environmental physics is that quantitative study of the meteorological measurements from this period is of questionable value. This is because the instruments were inadequately calibrated and, despite being built by craftsmen, were frequently repaired and used by a wide variety of people with unknown skills. In contrast to these views, recently rescued late eighteenth-century instrumental records of weather are being concatenated with modern climatic records, albeit after careful comparisons and evaluation (Frauenfeld et al. 2011). Our goal is to explore these conflicting perceptions of early instrumentderived weather measurements as quantitative climate records, as an exemplar of the need for increased openness in climate research. The case of Australia is chosen because the British settlement was of convicts, their guards, and administrators, so that although there was a clear need to understand climate for effective agriculture and to nurture water supplies, the invading force had little or no meteorological training (Phillip 1789).

\section{b. Climate reconstruction}

Historical records of temperature are a constant source of discussion in climate science (e.g., Nicholls 1988; Jones and Henderson-Sellers 1992; Jones et al. 2001; Wheeler et al. 2010; Brázdil et al. 2010). Although 
it is not until the mid-1800s that a consistent global observational record becomes established, there are many observations of temperature over the century preceding this that allow, or at least appear to allow, a longer record in a number of important locations. Many of these records have been examined in detail (e.g., Vinther et al. 2006; Gergis et al. 2009). However, temperature records in these early periods have significant problems (e.g., Box 2002; Garcia-Herrera et al. 2005a). They represent information gathered in a totally different social and technical environment, at a time when the quantification of the concepts of heat and cold was a novelty (e.g., Roebuck 1775) and when the scientific understanding of temperature aspects of the weather was limited (cf. Golinski 2007). They are from an era when instruments were handcrafted and therefore individual and when characteristics we take for granted today (such as the fixed points of the temperature scale) were not only in dispute but were very difficult to define (McConnell 2005). Most importantly, the background and education of observers and interpreters of the observations differed significantly. While other British colonies generally benefitted from well-educated (wealthy) invaders, this was not true in the early period of British settlement of New South Wales.

Reconstructions of a quantitative record of climate are admirable, having a heritage extending over the reconstruction of the central England temperature series by Manley $(1953,1974)$ through Hubert Lamb's work (e.g., Lamb 1995) to the present day [e.g., Atmospheric Circulation Reconstructions over the Earth (ACRE; Allan et al. 2011), IMPROVE project (Camuffo and Jones 2002), and the Millennium European Climate Project (Wheeler et al. 2009)]. However, there is often no explicit statement about instrument error and uncertainty. This is because uncertainty is frequently undocumented and, due to instrument loss or degradation, today unknowable. The overall spectrum of quality and homogeneity issues that affect any historical time series are assumed to be included in total uncertainty statements or taken as averaged out in composites. Improved estimates of the effect of instrument error and inhomogeneity issues are still actively being sought (e.g., Brunet et al. 2010), and time series are periodically reevaluated and updated in the light of new information (e.g., Parker and Horton 2005).

Our study serves to underline this uncertainty. Our evaluation involved curators from the United Kingdom's Science Museum, current and past, as well as experts in meteorological history in Australia and the United Kingdom. During an investigation of instruments equivalent to those transported to Australia in the period 17881840 , some museum (instrument) curators made the following comments:
- "The dates for invention of the thermometer, barometer, etc. do not mean that they were accurate then-by no means."

- "The crudity of (instrument) manufacture at that time-when craftsmen had difficulty making an even-bore tube-presented real problems."

- "Shipping barometers and thermometers to Australia meant carrying them through the tropics and that is where many broke as the mercury expanded and shattered the glass."

- "If the glass and mercury was transported separately, and assembled on arrival, with no reliable standard barometer to compare with, this was not always the answer."

- "The problem with barometers carted round the world is that they could get broken and then have the glass tube restored-sometimes in London at the original maker, but possibly in a distant port by some less skilful person."

- "Against what standard have they [the instruments] been adjusted?"

- "The whole idea of assessing the reliability and comparability of measurements was hardly confronted in 1800."

Such (curators') perceptions of the instruments and observations from the late eighteenth century are not original. The Societas Meteorologica Palatina was founded in Mannheim in 1780, for example, specifically to compare meteorological observations across Europe. Its activity was immediately curtailed by the extant problem of the total lack of standardization of instruments (e.g., Cappel 1980; Cassidy 1985).

\section{Historical view of early Australian meteorological instruments}

\section{a. Uncertainty in meteorological measurements around 1780}

Modern temperature measurements use resistance and other characteristics but, in the eighteenth century, the property typically used in thermometers was the change of volume of some thermometric substance in response to a change in the warmth or cold (Middleton, 1966). Thermometers in the 1760s-1780s were calibrated by two fixed reference points to define a linear relationship between the thermometric property and (what we know as) temperature (e.g., Chang 2004). Considering a simple liquid-in-glass thermometer, uncertainties can arise from uncertainties in the chemical composition of the medium (e.g., the presence of water in an alcohol thermometer may introduce some nonlinear behavior); from a dependence of the coefficient of thermal expansion on 
TABLE 1. Meteorological observations in and around the New South Wales coast between 1788 and 1840.

\begin{tabular}{lll}
\hline \hline \multicolumn{1}{c}{ Dates } & \multicolumn{1}{c}{ Observers } \\
\hline 1787-92 & Lieutenant William Bradley & \multicolumn{1}{c}{ Location } \\
1787-93 & John Easty & Onboard the Sirius (Sydney, Norfolk Island) \\
From 1788 & Many diarists & First Fleet diarist \\
1788 onward & Matthew Flinders and P. P. King and others & e.g., Goulburn from the 1820s \\
14 Sep 1788-6 Dec 1791 & Lieutenant William Dawes & Dawes Point, Sydney \\
1792-1810 & Unknown & Probably Government House, Sydney \\
$\begin{array}{l}\text { From Dec 1821 (officially May 1822) } \\
\text { beyond Brisbane's departure }\end{array}$ & $\begin{array}{l}\text { Governor Brisbane's staff (Charles Rumker } \\
\text { in Dec 1825) }\end{array}$ & $\begin{array}{l}\text { Old Government House Observatory, Rose Hill } \\
\text { (Parramatta) }\end{array}$ \\
April 1840 onward & Official weather observers & South Head, Sydney \\
\hline
\end{tabular}

temperature; from physical imperfections in the manufacture of the capillary; from temperature differences between the thermometer bulb and column; and from errors made in the calibration of the thermometer (e.g., Home and Livingston 1994). Although the users of early thermometers made much of the first three factors, the dominant factor in the accuracy of a thermometer at this time (when seen in retrospect) was the calibration of the device (e.g., Cotte 1788; Glaisher 1849, 1850).

For example, in 1772, in a dedicated attempt to tie down calibration points, Jean-André De Luc conducted extensive experiments into the nature of boiling (De Luc 1772). He succeeded in creating a sample of pure water from which all the air had been removed (a process that included carrying a flask of water around for four weeks while agitating it). By that time, the freezing point of water (or at least the temperature of an icewater mixture) was a well-accepted fixed point but many uncertainties remained at the "top" of the thermometric scale. De Luc found that his "pure" sample boiled at a temperature indicated by his thermometer as $112^{\circ} \mathrm{C}$.

Issues with barometers around this time included the problem that "ordinary" barometers do not work on board a moving ship. The first reliable marine barometer seems to have been made by Nairne for James Cook's second expedition. Thus, marine barometers, operating always at sea level, have short scales showing only 29 to 31 inches of mercury. At the other extreme, "mountain barometers" were constructed with capacious cisterns and extended scales, reading down to 25 inches or lower in the Alps. Worse even than "ordinary" barometers were some of those in domestic use, say for example the "banjo" barometers with a mechanism rather than a simple tube of mercury, making them much less accurate (Middleton 1964). Finally, for measurement of atmospheric pressure there were also sympiesometers that were fragile and not very reliable. Oil-based and more sensitive to pressure changes than mercurial barometers, their value at sea lay in a faster response than a mercury marine barometer to a sudden fall of pressure, indicating the approach of a hurricane. Sympiesometers (the most common make was the Adie) only become widespread between the 1820s and mid-1850s, having been first used in 1818 on board the Isabella in one of the early Arctic voyages (McConnell 2005).

\section{b. Quantifying the Australian climate}

The time of the British establishment of its penal colony in New South Wales (Australia) coincided with a period of intense effort and rapid scientific advances in atmospheric physics. Not only were thermometers and temperature scales being invented but pressure measurement was under intense scrutiny not so much for its own sake as for the potential it offered to measure the heights of mountains and the depths of mines [e.g., Recherches sur les Modifications de L'Atmosphere (1772) by Jean André De Luc]. The Royal Society appointed a committee to address the issue of calibrating thermometer scales and the result was a widely distributed report in 1777 that recommended specific calibration procedures with two fixed points defined by a freshwater-ice bath $\left(32^{\circ} \mathrm{F}\right)$ and a contained boiling water-steam vessel $\left(212^{\circ} \mathrm{F}\right)$ at a barometric pressure of 29.8 inches (Cavendish et al. 1777).

Australia's first official Meteorological Observatories were established in 1840 by order of the Colonial Secretary's Office (Table 1). Observations began in April 1840 at South Head, Sydney, Port Macquarie, and Port Phillip (Melbourne) (e.g., Loewe 1965). In Sydney, the observer was kept on until 1855. There seems to be little reason to suppose that meteorological instruments "exported" to Australia during colonization were less sound than those used elsewhere in the British Empire.

\section{The first $\mathbf{5 0}$ years of European observation of Australia's climate}

\section{a. Contextualizing Australia's instrumented climate from 1788}

During the period considered here, from William Dawes' arrival in January 1788 until the establishment of 
Australia's first official meteorological observatory at South Head in April 1840, the climate of Sydney and coastal New South Wales was noted, diarized, and, quite literally, written home about (e.g., Laurie 1988; see also our Table 1). Our research explores not the climate per se-which is well reviewed in, for example, Nicholls (1988) and Gergis et al. (2010b)_but rather the quantitative value of instrumental weather measurements made in this period. That this was a concern back in Britain is indisputable (e.g., Six 1794). Here we question the degree to which those invading Australia were capable of integrating meteorological and hydrological observations made in New South Wales between 1788 and 1840 into a view congruent with our modern understanding of the climate of Australia (Nicholls 1998; Golinski 2007). The analysis is solely European because the British settlers unwisely ignored indigenous knowledge of the climate, including very detailed interpretations by Aboriginal people (Green et al. 2010; cf. Turner and Clifton 2009).

There was no lack of interest in climate in early British Australia. The colony's food and water shortages frequently prompted rationing and appeals to other parts of the Empire for supplies: the First Fleet Captain, Governor Arthur Phillip, sent to South Africa for more provisions in May 1789 and Governor Macquarie ordered 250 tons of wheat from Bengal "to avert a famine" in December 1814. Early settlers searched river estuaries north and west of Sydney Cove to locate good land to farm but anecdotal evidence suggests that meticulous weather observations were not used (e.g., McAfee 1981). The Parramatta River was explored by Arthur Phillip, who established an early farm at what was called the "Crescent at Rose Hill" in November 1788 (Phillip 1789). Historical records underline the urgent need to understand, and thus project, climate in Australia, not least to satisfy the demands by governors of the colony, who needed to make politically embarrassing (even careerlimiting) requests for supplementary food if adequate supplies could not be grown locally (Goulburn 1825).

The new colonists in New South Wales faced very many challenges in everyday life including inadequate food, intermittent water (floods alternating with droughts), and deadly insects and snakes. Their weather observations were also challenged in ways not considered by modern meteorologists; for example, they were unsure of the exact longitude of their location (Bradley 1969). They also faced the same technical and intellectual challenges as other natural scientists of this period: poor (or poorly calibrated) instruments, incomplete understanding of the physics underlying the observable facts, and incomplete conceptual frameworks into which they could place their observations (De Luc 1772; Wright 1785). The tools and techniques available to the British First ${ }^{1}$ (1788) through Third (1791) Fleet sailors and marines and subsequent colonizers and natural scientists (Kington 1997) derived from eighteenth-century European knowledge, their education, and (for some) their instructions or job specification. We consider the connections among science, technology, and society (because climate is much more than a background for invasion and migration; Black et al. 2011) in the particular context of the early developmental pressures on the colony of New South Wales, Australia, whose governors were perplexed by massive floods and by frequent and devastating droughts (Russell 1887; Grove 2005).

\section{b. Locating themselves: The British in Australia}

The British colonies in "New Holland" commenced a "land grab" and some (notably in Sydney and Tasmania) were established to create offshore (from the United Kingdom) prisons. These colonies, unlike those of the East Indies or Americas, were not (at least at first) of particular interest to wealthy or educated settlers. Nonetheless, scientific observations were undertaken (for example to establish location, especially longitude, and distances within the colony as it was explored and mapped) and interpretation was demanded about weather and climate as well as many other natural features (e.g., King 1825).

Dawes' meteorological and astronomical observing position was not at what is now called Observatory Hill in central Sydney but at Dawes Point on the northern shore of the settlement where the southern pillar of the Harbour Bridge is located (Fig. 1). The location of Dawes' observations is said to be "unknown" by Gergis et al. (2009), who correct the pressure measurements for an elevation of $40.2 \mathrm{~m}$ (Bureau of Meteorology station 066062). All accounts, except that of Dawes, give the latitude as $33^{\circ} 52^{\prime} 30^{\prime \prime} \mathrm{S}$ - around $2.2 \mathrm{~km}$ south of the actual location. There is also discrepancy in the recorded longitude, as shown below:

- Lieutenant William Bradley calculated the longitude of the observatory site using 176 lunar-distance measurements as $151^{\circ} 20^{\prime} \mathrm{E}$ (Bradley 1969).

- The description from the journal of Arthur Phillip (Phillip 1789) gives coordinates of the observatory almost at Lord Howe Island: "On the point of land that forms the west side of the Cove, and on an elevated spot, a small observatory has been raised under the direction of Lieutenant Dawes, who was charged by the Board of Longitude with the care of observing the expected

\footnotetext{
${ }^{1}$ The First Fleet is the 11 ships led by Captain Arthur Phillip, which arrived in NSW in January 1788; the Second Fleet (6 ships) arrived in June 1790 and the Third Fleet (11 ships) in early 1791.
} 


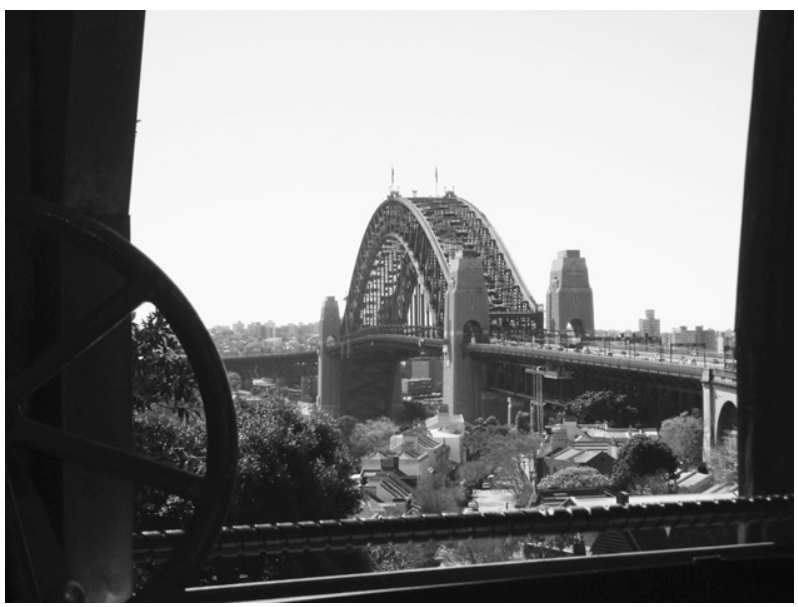

FIG. 1. Sydney Harbour Bridge looking north through the dome slit of the present-day observatory. The location of Dawes Point (the first observing post in European Sydney) is under the base of the nearest pillar of the bridge. [Photo courtesy of Kendal McGuffie.]

comet. The longitude of this observatory is ascertained to be $159^{\circ} 19^{\prime} 30^{\prime \prime}$ east from Greenwich." Assuming a transcription error, this is most likely $151^{\circ} 19^{\prime} 30^{\prime \prime} \mathrm{E}$.

- Colonel Collins in "An Account of the English Colony in New South Wales" (entry for February 1788) says: "Among the buildings that were undertaken shortly after our arrival must be mentioned an Observatory, which was marked out on the western point of the cove, to receive the astronomical instruments which had been sent out by the Board of Longitude, for the purpose of observing the comet ... longitude, from Greenwich, $151^{\circ} 19^{\prime} 30^{\prime \prime} E^{\prime \prime}$. (Collins 1798, Vol. I, p. 15)

- William Dawes wrote to Maskelyne in a postscript to a letter dated 17 November 1788, "I have assumed the Longitude of the Observatory at $10 \mathrm{~h} .05^{\prime} 24^{\prime \prime} \mathrm{E}$. $^{2}$ The Latitude I found roughly by the astronomical quadrant mounted on the stump of a tree saw'd off, in the open air to be $33^{\circ} 52^{\prime} 20^{\prime \prime}$; but by the zenith distances accompanying this I take it to be about $33^{\circ} 51^{\prime} 18^{\prime \prime}$. (Dawes 1788-91).

The most popular position $\left(33^{\circ} 52^{\prime} 30^{\prime \prime} \mathrm{S}, 151^{\circ} 19^{\prime} 30^{\prime \prime} \mathrm{E}\right)$ is approximately $3.8 \mathrm{~km}$ off the coast of New South Wales (NSW) due east of Rodney Reserve, Dover Heights, NSW, and more than $11 \mathrm{~km}$ away from Dawes Point, Sydney. These errors are commensurate with those of the coincident French expeditionary force that landed at La Perouse. Their astronomer Dagelet's calculated

\footnotetext{
2 This longitude was recorded in "hours" east of Greenwich, the figure converting to $151^{\circ} 21^{\prime} \mathrm{E}$.
}

longitude, which was probably as accurate as the tools and the period permitted, places his tent observatory about 18 kilometers to the east of its actual location (Morrison and Barko 2009).

The links between astronomy and meteorology in British New South Wales began with William Bradley and William Dawes (Table 1) and continued to encompass the very important topic of longitude and location for many years (e.g., Wolfendale 1997). Efforts were comparable with other parts of the British Empire; see, for example, "A meteorological diary kept at Fort St. George in the East Indies ... observed at three fixed times daily with a Nairne thermometer and Ramsden barometer" (Frängsmyr et al. 1990; see also Roxburgh and Pringle 1778).

\section{c. Understanding the physics of the atmosphere and climate (1780-1840)}

Lt. William Dawes and observers who followed him to Australia after 1788 could, in principle, have carried a "full set" of meteorological instruments since these all existed by the time of the First Fleet's invasion (Table 2). Galileo created a thermoscope in the 1500s; Torricelli invented the barometer in 1644; Blaise Pascal demonstrated that atmospheric pressure decreased with height in 1648 and Robert Hooke invented the (plate) anemometer in 1667. Charles Le Roy recognized dewpoint temperature as the point of saturation of air in 1751 and Horace de Saussure created the "last" basic meteorology instrument, the hair hygrometer for measuring humidity, in 1780 .

Some conceptual components of atmospheric physics necessary for climate comprehension also existed, such as the fundamental gas law of Robert Boyle (from 1662) and the first essentially correct explanation of global circulation, which followed from George Hadley's study of the trade winds in 1735 (Hadley 1735). However, Gaspard de Coriolis' recognition that the rotation of the Earth causes a force in the atmosphere would not occur until 1835 and (atmospheric) thermodynamics was in its infancy. Most particularly, Joseph Black's concepts of latent heat and specific heat had only been described in 1761 and critically important theories and inventions were yet to eventuate (Table 2).

While the need for fixed points of temperature was well known, achieving these reliably was technically difficult and scientifically disputed (De Luc 1772), rendering the calibration of the scale of temperature uncertain late in the eighteenth century (Chang 2004), despite the Royal Society findings described by Cavendish et al. (1777). Inventors created new thermometers (McConnell 1992) and industrialists and researchers investigated extreme phenomena such as the firing temperatures of pottery 
TABLE 2. Meteorological and atmospheric physics breakthroughs around the time of the British settlement of Australia.

\begin{tabular}{lll}
\hline \hline Date & \multicolumn{1}{c}{ Theory or invention } & \multicolumn{1}{c}{ Originator } \\
\hline 1761 & Concepts of latent heat and specific heat & Joseph Black \\
1780 & Hair hygrometer for measuring humidity & Horace de Saussure \\
1782 & First balloon flight measuring temperature and pressure & Jacques Charles \\
$1801-03$ & Laws of pressures of vapors & John Dalton \\
1804 & Balloon ascent to study weather & Joseph Louis Gay-Lussac \\
1805 & Law of pressure variation with height & Pierre Simon Laplace \\
1841 & Convection theory of cyclone energy described & James Pollard Espy \\
\hline
\end{tabular}

(Wedgwood 1784) and the freezing point of mercury (Hutchins 1783).

Ship logbooks are just now becoming valued as a climatological resource (e.g., Garcia-Herrera et al. 2005b). The logs and journals of the voyages of Cook and Dampier, and the Dutch and other navigators before them, all contained meteorological observations. However, as Garcia-Herrera et al. (2005a) explain, these were not designed to be weather records: "pre- and post-1854 instrumental data are not easily combined, as in the early period; for example, only rarely a thermometer was attached to the barometer, and height corrections to pressure were probably not applied." (Garcia-Herrera et al. 2005a, p. 5).

Wheeler et al. (2010) confine their analysis to the English Channel and its western approaches where "the abundance of logbooks for this period allows for the abstraction of a daily series of wind force and direction data" (Wheeler et al. 2010, p. 257). Synoptic weather observations lacked a single agreed nomenclature for many basic features: Luke Howard (1803) proposed the accepted cloud classification just two years before Francis Beaufort's (1805) official codification of wind speeds, although the British Royal Navy had employed this wind force vocabulary informally for some years (e.g., Wheeler and Wilkinson 2004). Finally, the means of collecting temporally coincident observations had, of course, to await the telegraph (mid-1850s).

\section{d. Who observed and might have understood Australia's climate?}

\section{1) Lieutenant WiLliam BRAdLEy}

Lieutenant William Bradley, who landed in Sydney Harbour from the Sirius on 26 January 1788, is said [by Laurie (1988), p. 475] to be "almost certainly the greatnephew of James Bradley," Astronomer Royal from 1742 to 1762 . The pressure observations taken by Bradley during the voyage of the First Fleet to Australia between 1787 and 1788 do not agree with modern observations very well (e.g., Fig. 2) although Bradley's records from on board the Sirius while anchored in Sydney Harbour are used by Gergis et al. (2010a).

\section{2) Lieutenant William Dawes}

William Dawes, a Lieutenant of Marines, under instruction and patronage of the English Astronomer Royal, Nevil Maskelyne, ${ }^{3}$ arrived in Australia 18 January 1788 on the Supply, ${ }^{4}$ a ship of the First Fleet. Dawes made the first instrumented land-based meteorological and astronomical observations in Australia ${ }^{5}$ (cf. Morrison and Barko 2009). His journal (located by Robert McAfee in 1977) is archived in The Royal Society collection in London. It reveals a meticulous observer recording wind direction and speed, cloud cover, barometer reading and temperature, rainfall, and dewfall taken, in most cases, four times each day, from his observatory erected in 1788 at the place now known as Dawes Point. Dawes failed to observe Halley's comet, which was his main commission from Nevil Maskelyne, but did write to him numerous times giving details of his work.

Dawes set up the meteorological and astronomical observing post at $33^{\circ} 52^{\prime} 30^{\prime \prime} \mathrm{S}, 151^{\circ} 19^{\prime} 30^{\prime \prime} \mathrm{E}$ at the foot of the Sydney Harbour Bridge (Table 3; Fig. 1). The two thermometers were exposed "outside away from direct sunlight and about three feet above a stone surface" (Kington 1997). According to Dawes' drawings and letters both rooms had canvas shutters, which were opened to view the night sky (Dawes 1786-92). Dawes used a barometer made by Burton supplied by the Board of Longitude but he thought it was not properly operational.

\footnotetext{
${ }^{3}$ Dawes held a position (with attendant responsibilities) as a lieutenant. He was also directed by Maskelyne to make astronomical observations and supplied with instruments by the Board of Longitude for this purpose (cf. Minutes of the Board of Longitude, November 14, 1786). [Dawes frequently complains in letters that his duties inhibit his observations; e.g., Laurie (1988).]

${ }^{4}$ Arthur Phillip transferred from the Sirius to the Supply after leaving Cape Town (taking Dawes with him) in order to arrive more quickly in Australia. [In fact Supply arrived only 2 days before the Sirius.]

${ }^{5}$ Dawes was appointed to make astronomical observations on the voyage, but he was not paid to conduct astronomy (or meteorology) on land or to erect an observatory. His duties were described in the land detachment position he was given by Phillip, which included exploration and surveying (Laurie 1988, 474, 481).
} 


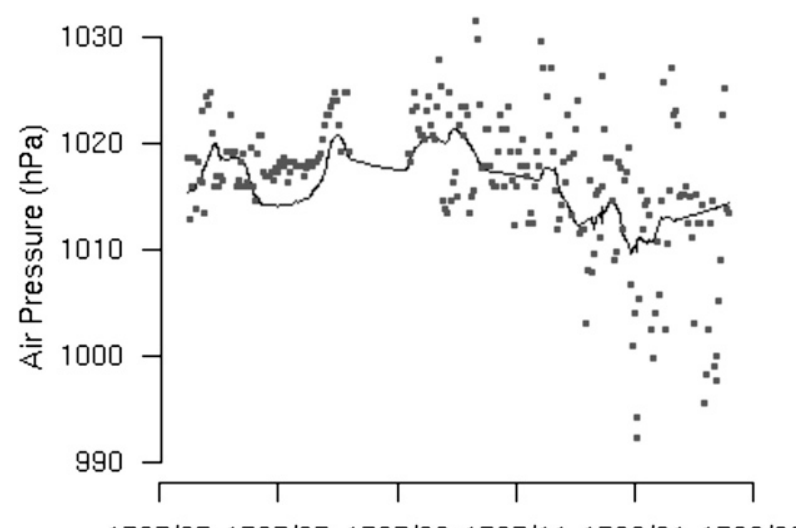

$1787 / 05 \quad 1787 / 07 \quad 1787 / 091787 / 11 \quad 1788 / 01 \quad 1788 / 03$

\section{Date}

FIG. 2. Bradley's pressure observations (square dots) taken on board the Sirius during the First Fleet voyage. Bradley's barometer measurements (square dots) do not agree with the modern pressure measurement along the same route (line superimposed) [Graph sourced from OldWeather web in August 2010; see http://www. oldweather.org/about.]

Inspection of the location today suggests that his observations were made no more than $20 \mathrm{~m}$ above sea level and more likely around $15 \mathrm{~m}$ (Fig. 1). R. J. McAfee (1981, personal communication) conjectures that the barometers were most likely located inside with a thermometer attached, as was the practice at that time. It is assumed that the instruments were collocated in a wellventilated position inside the observatory-a canvasroofed, circular observation room. There was no fireplace in the observatory (McAfee 1981) and Gergis et al. (2009, p. 84) deduce that "from the daily range of temperatures, he [McAfee] suggests that there seems little reason to suspect a very airtight or heated room exposed to direct sunlight."

Dawes noted that the Burton barometer was imperfect (McAfee 1981) (with corrections from the original):

It was my intention to have it [the barometer] examined on its return to England, as, owing to the maker [NB both McAfee and Gergis et al. erroneously give this word as "marker"] having depended upon glue to keep the cistern tight where it had been crack'd, it had lost [NB both McAfee and Gergis et al. erroneously give this word as "but"] a small quantity of quicksilver, which I had discovered by observing a number of very small globules immediately under it on the floor of the observatory.

This faulty barometer was replaced by a Ramsden model "supplied by 'Mr Furzer' in the colony" [a quartermaster on the Sirius]. Dawes' Board of Longitudesupplied thermometer (by Nairne and Blunt) was briefly compared with one by Ramsden also lent to him by Mr. Furzer (see Fig. 3) (Dawes 1788-91).

\section{3) Governor Thomas Brisbane}

Thomas Brisbane, when told of his appointment to Governor of NSW, collected a library of astronomical books and instruments and engaged Mr. Charles Rumker and Mr. James Dunlop. The three men arrived in the colony in November 1821, chose a site for the (Astronomical) Observatory close to Government House, Parramatta, and began its construction. It was officially opened in April 1822 (Bhathal 2011). Meteorological observations were recorded from May 1822 (Field 1825) to March 1824 and probably much longer. [There is evidence ${ }^{6}$ of observations at Rose Hill continuing until August 1847 (Dunlop 1847)].

\section{4) DiARISTS AND EXPLORERS}

Other First, Second, and Third Fleet occasional observers/recorders of the weather included Ralph Clark (1787-92) and Richard Atkins (1792-1810), but note that R. J. McAfee (1981, personal communication) comments that "many of the superlatives in writings" were as a result of the difference between English and Australian weather rather than denoting extremes in themselves. Weather observations were made (presumably by British agents) and published in the Sydney Gazette (Fig. 4) by the beginning of the nineteenth century (e.g., Watson 1914).

Despite the absence of definitive quantitative data, within six months of arrival, Arthur Phillip wrote in his journal in 1788 :

The climate at Sydney Cove is considered, on the whole, as equal to the finest in Europe. The rains are not ever of long duration, and there are seldom any fogs: the soil, though in general light, and rather sandy in this part, is full as good as usually is found so near the sea-coast. All the plants and fruit trees brought from Brasil and the Cape, which were not damaged in the passage, thrive exceedingly; and vegetables have now become plentiful, both the European sorts and such as are peculiar to this country. In the Governor's garden are excellent cauliflowers, and melons very fine of their kinds. The orange trees flourish, and the fig trees and vines are improving still more rapidly. In a climate so favourable, the cultivation of the vine may doubtless be carried to any degree of perfection; and should not other articles of commerce divert the attention of the settlers from this point, the wines of New South Wales may, perhaps, hereafter be sought with avidity, and become an indispensable part of the luxury of European tables. (Phillip 1789, ch. 13)

\footnotetext{
${ }^{6} 22$ Apr 1831: "Let it be notified that the Secretary of State has been pleased to appoint Mr. James Dunlop, Superintendent of the Government Observatory at Parramatta, with a salary of $£ 300$." (Signed) R. A. Darling at Government House.
} 
TABLE 3. Dawes' and Brisbane's observing situation and instruments.

\begin{tabular}{|c|c|c|c|c|c|}
\hline Observer & Dates & Location & Temperature & Pressure & Other \\
\hline $\begin{array}{l}\text { William } \\
\text { Dawes }\end{array}$ & $\begin{array}{r}14 \text { Sep } 1788- \\
6 \text { Dec } 1791\end{array}$ & $\begin{array}{l}33^{\circ} 52^{\prime} 30^{\prime \prime} \mathrm{S}, \\
151^{\circ} 19^{\prime} 30^{\prime \prime} \mathrm{E} \text { at } \\
\text { Dawes Point on } \\
\text { Sydney Harbour }\end{array}$ & $\begin{array}{l}\text { Nairne \& Blunt } \\
\text { thermometer }\end{array}$ & $\begin{array}{l}\text { Burton barometer } \\
\text { (broken); a } \\
\text { borrowed Ramsden } \\
\text { barometer }\end{array}$ & Many astronomical \\
\hline $\begin{array}{l}\text { Thomas } \\
\text { Brisbane }\end{array}$ & $\begin{array}{l}\text { Oct } 1822-\text { Mar } 1824 \\
\text { and probably at } \\
\text { least into the } \\
1830 \text { s }\end{array}$ & $\begin{array}{l}33^{\circ} 48^{\prime} 44.50^{\prime \prime} \mathrm{S} \\
150^{\circ} 59^{\prime} 49.49^{\prime \prime} \mathrm{E} \text { at } \\
\text { Old Government } \\
\text { House, Parramatta }\end{array}$ & $\begin{array}{l}\text { Thermometer(s) } \\
\text { of unknown } \\
\text { manufacture }\end{array}$ & $\begin{array}{l}\text { Barometer by Banks } \\
\text { and two mountain } \\
\text { barometers, one by } \\
\text { Troughton }\end{array}$ & $\begin{array}{l}\text { Eirometer, by Jones } \\
\text { Hygrometer, by Saussiere } \\
\text { (transcribed error for } \\
\text { Saussure); Many astronomical }\end{array}$ \\
\hline
\end{tabular}

Various journeys of exploration both by land and by sea included some meteorological measurements-for example (only one of very many), Field (1825) includes the full journal of Capt. M. J. Currie that describes "an excursion southward of Lake George in New South Wales" (Currie 1825) and in its appendix lists the temperature measurements made on this trip. There were even prayers offered for drought-breaking rains (e.g., in 1829). Throughout this period, there were no professional meteorologists in the colony (cf. Loewe 1965). Even by 1840, when "formal" meteorological observations were commanded by the Colonial Secretary's Office, the Australian observers were drawn from the "educated" convicts.

\section{5) Government Meteorological OBSERVATORIES}

Although it is uncertain which meteorological instruments Brisbane brought with him in 1821, we do know what the Parramatta observatory instruments included by 1847 (Table 3).
Australia's first official Meteorological Observatories were established in 1840 by order of the Colonial Secretary's Office dated 10 March 1840 that said:

"Sir,- - I am directed by His Excellency the Governor to transmit to you the copy of a circular despatch, dated 29th November, 1838, from Lord Glenelg, relating to the "Collection of Facts respecting Storms," and to acquaint you that persons who have been under the instruction of the Astronomer at Parramatta have been appointed to register observations at 1s. 6d. per day each, in lieu of clothes and rations.

I am further directed to inform you that these men are convicts taken from the class of specials who not being assignable are always maintained at the expense of the Government, the charge above mentioned will properly be defrayed out of convict funds."

Meteorological Observatories were accordingly established in Sydney and Melbourne with observations beginning in April 1840 (Loewe 1965, 1970; Watson 1914).

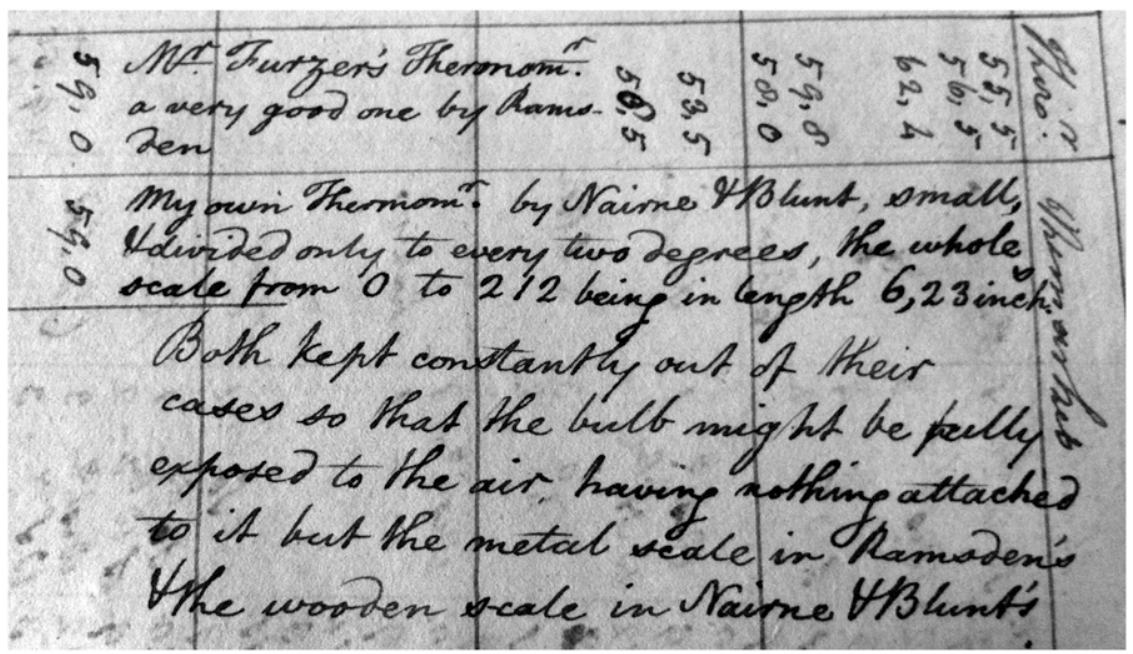

FIG. 3. Extract from William Dawes' journal mentioning the comparison he made between his own Nairne and Blunt thermometer and one by Ramsden borrowed from Mr. Furzer. Dawes installed a second thermometer ("a very good one by Ramsden's") on 3 July 1791, giving rise to a "Remark" in his observational record on 11 July 1791 ,"I observe when the thermometers have been long at nearly the same height that they agree." (Dawes 1788-91). [From microfiche in McAfee (1981), original at the Royal Society of London.] 


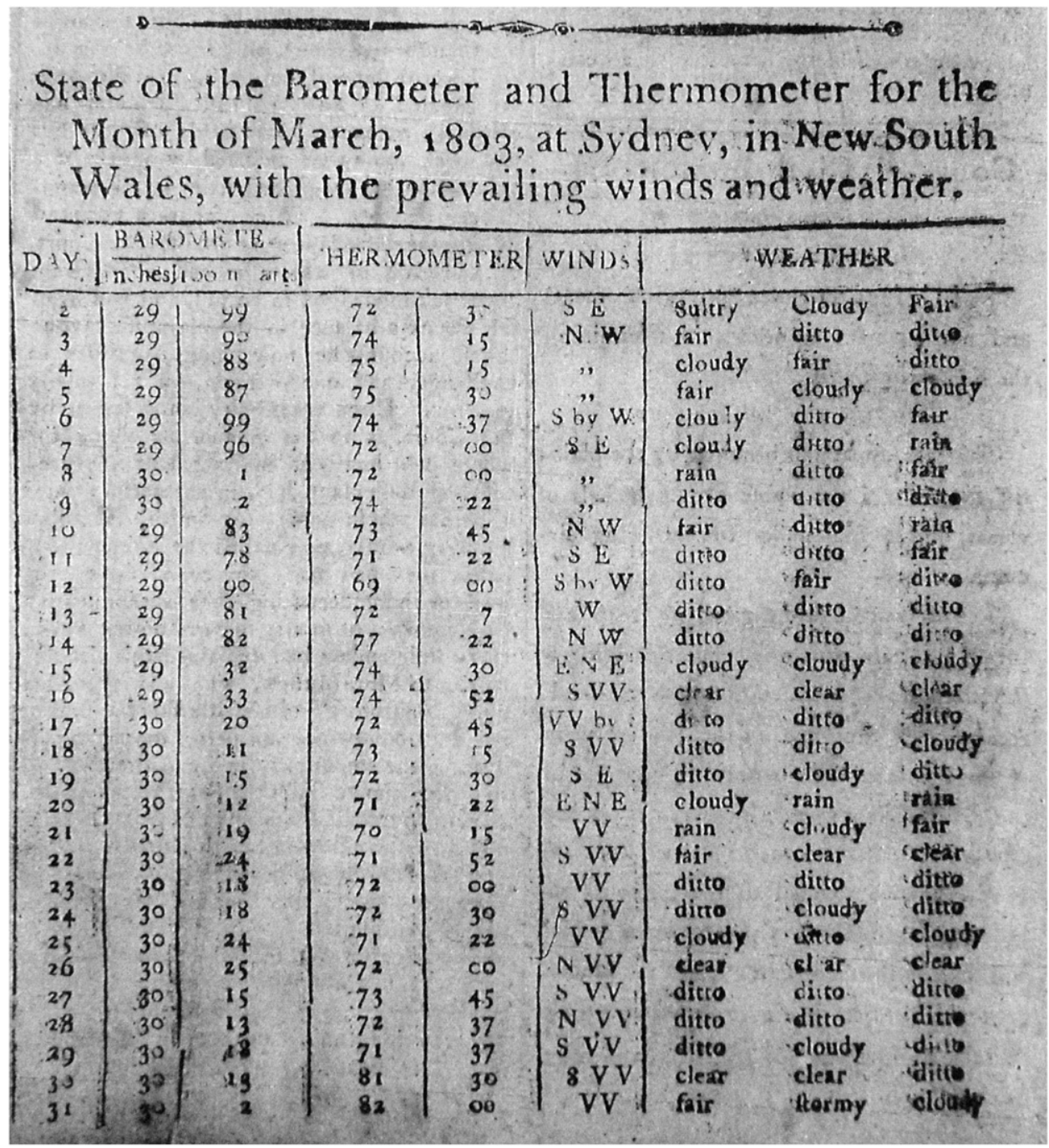

FIG. 4. Extract from the Sydney Gazette of 2 April 1803 showing very early newspaper publication of tabulated weather observations for March 1803. [Courtesy of the Mitchell Library, Sydney.]

\section{The first 50 years of British Australians understanding their climate}

\section{a. Climate comprehension and interdisciplinarity}

Lack of interdisciplinarity (cf. Phelan et al. 2012) may be in part responsible for the dichotomy of views of instrument-based weather records from the late eighteenth century: climate scientists rescue and exploit such records while museum curators dismiss single uncalibrated instrument records as quantitatively unusable. Although climatic research is currently criticized for its failure to embrace the breadth of the issues it impinges-see, e.g., Hulme's (2011, p. 177) comment: “[in the] IPCC's fourth assessment report and the forthcoming fifth assessment report, the analysis of anthropogenic climate change continues to be dominated by positivist disciplines at the expense of interpretative ones"- - only a few years ago, climate science was lauded for its disciplinary catholicism: "the desire to make climate models more realistic led to the involvement of many disciplines... no one discipline can assume constancy in the variables prescribed by the others" (McGuffie and Henderson-Sellers 2005, p. 66).

It is undoubtedly true that early British invaders landing around Sydney Cove encountered conditions dominated by large-scale ocean-atmosphere oscillations, especially the El Niño-Southern Oscillation (ENSO), inducing droughts and floods together with flooding following powerful "southerly busters," remnant tropical cyclones, and other east coast lows. Despite some high-quality observing, no modern integration of the Australian climate occurred until William Stanley Jevons' interpretation in 1858 (Jevons 
1859a,b,c; Nicholls 1998) of 16-18 years of detailed meteorological observations from Sydney's South Head. More comprehensive narratives such as H. C. Russell's Climate of New South Wales (1887) required a century building on another three decades beyond Clarke and Jevons (see also Russell 1896).

\section{b. Dangers of single instrument climate reconstructions}

The British colonizers of New South Wales made some very good astronomical observations and after serious initial difficulties managed to become successful in longitude determination and georeferenced mapping. These geographical, navigational, and astronomical measurements ${ }^{7}$ often prompted meteorological observations although weather and climate seems rarely to have been a scientific or observational priority (see our footnote 6; Kington 1997). European climate understanding in all the British colonies was predominantly by means of individuals' learning alone (e.g., Worgan 1788). There is some literature concerning this later in the colonization (e.g., Russell 1888) but very little more than the individuals' own notes during the first 40-50 years of settlement (Table 1).

In the European capital cities, reputed eighteenthcentury craftsmen had difficulty making an even-bore tube. Despite the understanding of the need for fixed points (e.g., Cavendish et al. 1777), the absence of an agreed standard against which these instruments could be calibrated presented a serious challenge. Transferring glass tube-based instruments (barometers and thermometers, e.g., Fig. 5) to Australia involved ship voyages, boat transfers, and often journeys on horseback or on horsedrawn carts. If transport breakage did not destroy these instruments then shipping through temperature and pressure extremes meant that many were broken as a result of rapid mercurial expansion. Separate transportation of glassware and mercury (or spirit) followed by assembly on arrival meant that calibration was impossible. Repairing glass tubes either involved a return to London and to the original maker, or possibly a fix by some less skillful person en route or at the destinatio$\mathrm{n}$-again without any chance of calibration. Exposure (e.g., indoors or outdoors; sunlit or shaded) also presented a "final" placement problem. All the anticipated (by museum curators) difficulties can be clearly seen in the recorded history of the first 50 years of British observation of the weather in New South Wales.

\footnotetext{
${ }^{7}$ Board of Longitude minutes 14 Nov 1786 state that "Mr William Dawes Lieutenant of Marines ... is desirous of making useful Navigational and Astronomical observation in his passage thither" (Laurie 1988, p. 470) (see our Fig. 5)
}

\section{1) InStrument BREAKAgES (E.G., DAWES AND DUNLOP)}

The operation of William Dawes' Board of Longitudesupplied Burton barometer was impaired by a crack in its cistern that allowed some of the mercury (quicksilver) to escape (McAfee 1981; Dawes 1788-91):

In packing it [barometer] up, however, I found a large crack in the cistern, thro' which perhaps all the quicksilver would have escaped in the course of the passage [back to England] and have endangered breaking the tube; I therefore emptied it entirely and then packed it up.

James Dunlop describes damage arising from incorrect exposure of glass instruments (Dunlop 1847):

in 1832 (Jan) ... the spirit level of the transit circle, by Jones, [was] burst by exposure to the sun a few months after it was set up [around 1822], the tube being filled with sulphuric ether, which boils at a very low temperature, far below the powerful influence of the solar rays.

\section{2) InADEQuAte CALIBRATion (E.G., DAWES)}

Most of the discussion of quantitative comparison of William Dawes' observations arises from pressure measurement. However, his journal also mentions a brief attempt at comparison he made between two thermometers: the Board of Longitude instrument made by Nairne and Blunt and a thermometer by Ramsden borrowed from Mr. Furzer. Dawes wrote that he installed a second thermometer ("a very good one by Ramsden's") on 3 July 1791 giving rise to a "Remark" in his observational record on 11 July 1791 (Fig. 3):

\section{I observe when the thermometers have been long at nearly} the same height that they agree. (Dawes 1788-91).

\section{3) InAdequate EXPerienCe (E.G., PhilliP AND DAWES}

Between them, Arthur Phillip, William Dawes, and Philip Gidley King allowed the vitally important Kendall K-1 timekeeper ${ }^{8}$ to run down during the period it was on board Supply [between Cape Town and Sydney]. Lieutenant William Bradley, in his First Fleet journal, noted on Friday 25 January 1788,

We received the Timekeeper from the Supply where it had unfortunately been let down on the passage to this place. (Bradley 1969).

\footnotetext{
${ }^{8}$ Kendall's marine chronometer [K1; “"copy of Harrison's prizewinning watch which Cook had taken on his second and third voyages" (Laurie 1988, p. 470)] supplied by Maskelyne to Arthur Phillip.
} 


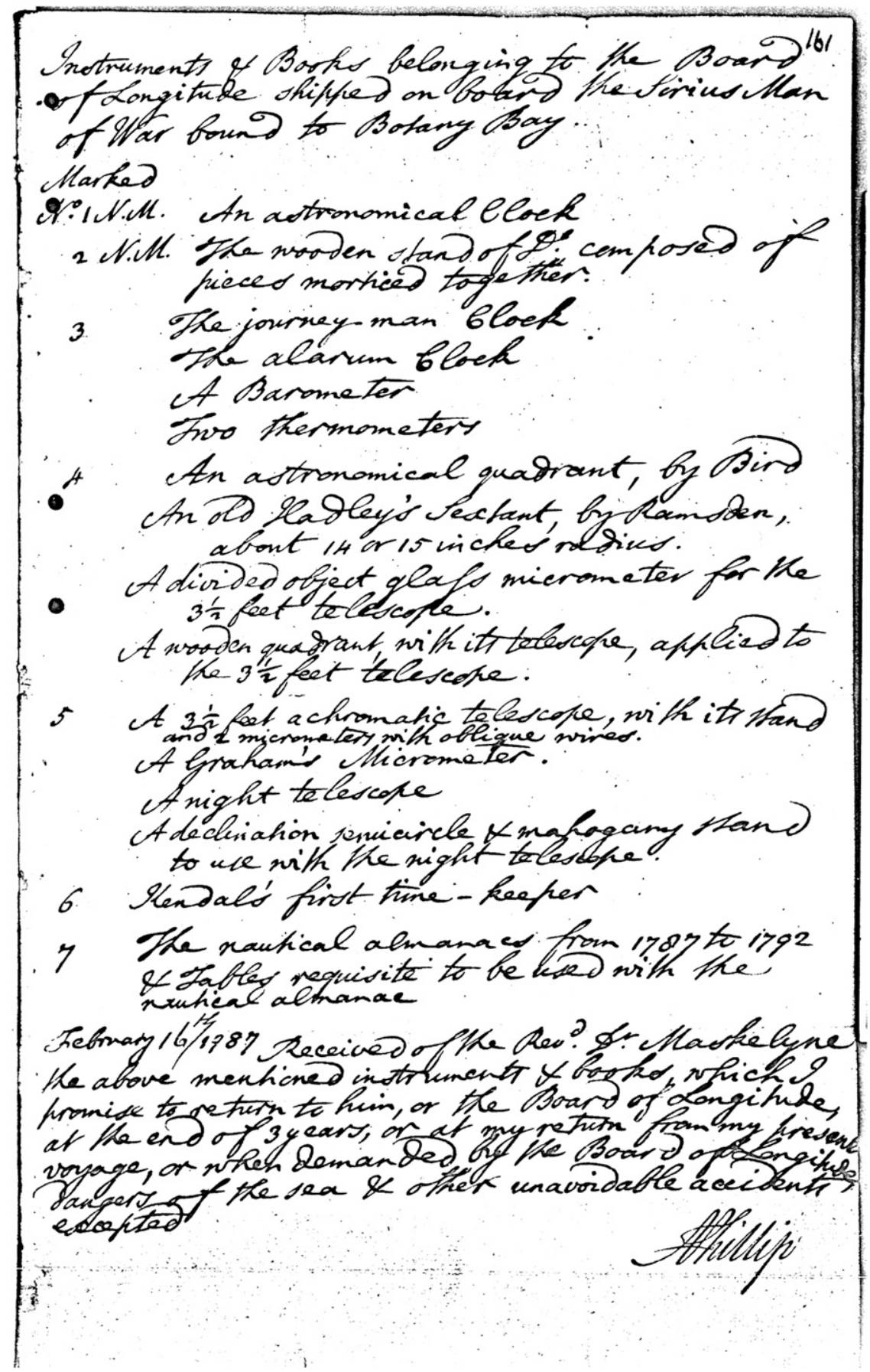

FIG. 5. Details of instruments received by Arthur Phillip on behalf of William Dawes for passage to Australia. [Courtesy Richard Dunn, Board of Longitude papers, p. 161.]

This serious error was confirmed by Dawes in a letter to Nevil Maskelyne (10 July 1788):

... whenever there is any thing to be got out of the hold, it is a very awkward rather dangerous thing to go from the quarter deck to the cabbin [sic] it was owing to this that on the 18th Decr. [1787] the time-keeper was let down, as
Captn. Phillip could not get down at noon to wind it up \& it was not thought of afterwards by anyone till near six o'clock at which time it had been down above an hour.... (Dawes 1788-91; Laurie 1988).

Dawes tried to reset this vital timepiece against an astronomical clock during September 1788 and found that 
it was losing $4.77 \mathrm{~s}$ per day over a 22-day period (Howse 1969). This was almost certainly the "Kendall's watch" which William Bradley established had in 2 months been losing at a rate of $5 \mathrm{~s}$ per day (Laurie 1988).

Dawes appears to have lacked experience with the Ramsden barometer (Gergis et al. 2010b; McAfee 1981) Dawes wrote in the back of his journal:

... Mr Furzer's [barometer] ... a very good one of Ramsden construction and is furnished with a gage point, tho' from the one I had before used, not having any such thing, and my then ignorance of the instrument, it was never attended to, but the bottom of the bag was let down as low as it would come and the observations made without attending to the gage point at all.

\section{4) Summary: The NeEd FOR CAUTION}

That eighteenth-century instruments posed serious challenges to early settlers in Australia is generally recognized; for example, Gergis et al. (2009) note that Dawes' observations of surface pressure taken between 12 July 1791 and 6 December 1791 appear to be far too low to be considered reliable. Similarly, surface pressure observations made by Bradley during the voyage of the First Fleet to Australia on board the Sirius between 1787 and 1788 do not mesh with modern observations (Fig. 2).

The difficulties faced by those attempting to understand the Australian climate included lack of instrument and/ or observational experience, poor/no/lost instrument calibration, instrument breakage, and distance from the original (or qualified) instrument makers and experienced scientific interpreters. These challenges can be compounded by (as we have shown here) transcription errors from original documents, and failure to clearly identify records from single instruments with unknown calibration can creep into carefully reconstructed histories.

\section{c. Conclusions}

In this research we have been concerned with the likely level of understanding of meteorological measurements made between 1788 and 1840 and also, importantly, the level of instrumental calibration and the scientific understanding of those making or receiving these observations. We examined the two sets of instruments (of Bradley/Dawes and those at Old Government House) that bracket the observational capabilities of the first European settlers in New South Wales from 1788 until formal and fully organized observation stations were established in 1840. We do not suggest that uncertainties related to late eighteenth-century thermometers have been neglected. Our primary interest is in the quality of observations made and the interpretation that may have been drawn from them regarding the climate of Australia from 1788 to the early nineteenth century. The individuality of available instruments and the prevalent lack of calibration against absolutes or even differently manufactured devices render quantitative measurements ambiguous at best and probably not comparable with or able to be concatenated to modern observations.

For early pressure and temperature observations, it seems likely that there will be an irreducible uncertainty ${ }^{9}$ that cannot be known and that must therefore impose a measure of caution in any subsequent interpretation and particularly in any application of these data. Thus despite the remarkable claim by Gergis et al. (2009) that William Dawes' data are commensurate with present-day meteorological measurements, there is a strong case for exercising caution when utilizing such historical climate data. Successful interpretations of such reconstructions will be enhanced by continuing interdisciplinary research that encourages open discussion of an apparent dichotomy of view about the accuracy of the instrumental data between historians of physics (including museum curators) and climate researchers.

Acknowledgments. The two authors shared a Science Museum of London Visiting Fellowship in 2011, designed to investigate the quantitative nature of climate observations from the British settlement of Australia. During this we examined over 100 period instruments and held discussions with Dr Peter Morris, Head of Research, Science Museum, London; Dr Peter Hingley, Chief Librarian, Royal Astronomical Society, Burlington House, London; Dr Richard Dunn, Head Curator, National Maritime Museum, Royal Greenwich Observatory, London; Dr Jane Insley, Curator and Researcher, Science Museum, London; Dr Anita McConnell, previously Senior Curator, Science Museum, London; Ms Tabitha Wood, Science Museum Library, Wroughton, Swindon; Mr Rory Cook, Corporate Information and Enquiries Officer, Science Museum, London; Ms Rebecca Cook, Blythe House, Science Museum, London; and Mr Rupert Baker, Library Manager, The Royal Society, London.

\section{REFERENCES}

Allan, R., P. Brohan, G. P. Compo, R. Stone, J. Luterbacher, and S. Brönnimann, 2011: The International Atmospheric Circulation Reconstructions over the Earth (ACRE) initiative. Bull. Amer. Meteor. Soc., 92, 1421-1425.

Averyt, K., 2010: Are we successfully adapting science to climate change? Bull. Amer. Meteor. Soc., 91, 723-726.

Bhathal, R., 2011: A governor's observatory. Astron. Geophys., 52, 2.31, doi:10.1111/j.1468-4004.2011.52231.x.

\footnotetext{
${ }^{9}$ On account of the virtual impossibility to have calibrated thermometers and barometers in eighteenth-century Australia.
} 
Black, R., W. N. Adger, N. W. Arnell, S. Dercon, A. Geddes, and D. Thomas, 2011: The effect of environmental change on human migration. Global Environ. Change, 21 (S1), S3-S11, doi:10.1016/j.gloenvcha.2011.10.001.

Box, J. E., 2002: Survey of Greenland instrumental temperature records: 1873-2001. Int. J. Climatol., 22, 1829-1847.

Bradley, W., 1969: A voyage to New South Wales: The journal of Lieutenant Bradley RN of HMS Sirius. Trustees of the Public Library of New South Wales, 195 pp.

Brázdil, R., D. Wheeler, and C. Pfister, 2010: European climate of the past 500 years based on documentary and instrumental data. Climate Change, 101, 1-6, doi:10.1007/s10584-010-9866-x.

Brunet, M., and Coauthors, 2010: The minimization of the screen bias from ancient Western Mediterranean air temperature records: An exploratory statistical analysis. Int. J. Climatol., 31, 1879-1895, doi:10.1002/joc.2192.

Camuffo, D., and P. Jones, 2002: Improved understanding of past climatic variability from early daily European instrumental sources. Climate Change, 53, 1-4.

Cappel, A., 1980: Societas Meteorologica Palatina (1780-1795). Ann. Meteor., 16, 10-27.

Cassidy, D. C., 1985: Meteorology in Mannheim: The Palatine Meteorological Society, 1780-1795. Sudhoffs Arch. Z. Wissenschaftsgesch., 69, 8-25.

Cavendish, H., W. Heberden, A. Aubert, J. A. DeLuc, N. Maskelyne, S. Horsley, and J. Planta, 1777: The report of the committee appointed by the Royal Society to consider of the best method of adjusting the fixed points of thermometers; and of the precautions necessary to be used in making experiments with those instruments. Philos. Trans. Roy. Soc. London, 67, 816-857.

Chang, H., 2004: Inventing Temperature: Measurement and Scientific Progress. Oxford University Press, 304 pp.

Collins, D., 1798 (cited 2011): An account of the English colony in New South Wales, with remarks on the dispositions, customs, manners, etc. of the native inhabitants of that country, to which are added, some particulars of New Zealand; compiled, by permission, from the Mss. of Lieutenant-Governor King. [Available online at http:// www.gutenberg.org/files/12565/12565-h/12565-h.htm.]

Cotte, L., 1788: Mémoires sur la météorologie, pour servir de suite \& de supplément au Traité de météorologie publié. Imprimerie royale, 2 Vols., $1251 \mathrm{pp}$.

Currie, M. J., 1825: Journal of an excursion southward of Lake George in New South Wales. Geographical Memoirs on New South Wales by Various Hands Together with Other Papers on the Aborigines, the Geology, the Botany, the Timber, the Astronomy, and the Meteorology of New South Wales and Van Diemen's Land, B. Field, Ed., J. Murray, 367-382.

Dawes, W., 1786-92: Correspondence during the establishment of an observatory at Port Jackson, N.S.W, The Royal Greenwich Observatory, Hailsham. Royal Greenwich Observatories Archives, Vol. 576.

__ 1788-91: Journal of meteorological records for Port Jackson, 1788-1791. Handwritten notebook held in The Royal Society, London, 115 pp.

De Luc, J.-A., 1772: Recherches sur les Modifications de l'Atmosphere (Inquiries on the Modifications of the Atmosphere). 2 Vols., 416 and 489 pp.

Dunlop, J., 1847: Letter of James Dunlop to the Board of Visitors of the Parramatta Observatory on 18th August 1847. Parramatta Observatory Doc. 47/6561.

Field, B., Ed., 1825: Geographical Memoirs on New South Wales by Various Hands Together with Other Papers on the Aborigines, the Geology, the Botany, the Timber, the Astronomy, and the Meteorology of New South Wales and Van Diemen's Land. J. Murray, 504 pp.

Frängsmyr, T., J. L. Heilbron, and R. E. Rider, Eds., 1990: The Quantifying Spirit in the Eighteenth Century. University of California Press, $411 \mathrm{pp}$.

Frauenfeld, O. W., P. C. Knappenberger, and P. J. Michaels, 2011: A reconstruction of annual Greenland ice melt extent, 1784-2009. J. Geophys. Res., 116, D08104, doi:10.1029/2010JD014918.

Garcia-Herrera, R., G. P. Konnen, D. A. Wheeler, M. R. Prieto, P. D. Jones, and F. B. Koek, 2005a: CLIWOC: A climatological database for the world's oceans 1750-1854. Climate Change, 73, 1-12, doi:10.1007/s10584-005-6952-6.

, C. Wilkinson, F. B. Koek, M. R. Prieto, N. Calvo, and E. Hernandez, 2005b: Description and general background to ships' logbooks as a source of climatic data. Climate Change, 73, 13-36, doi:10.1007/s10584-005-6954-4.

Gergis, J., D. J. Karoly, and R. J. Allan, 2009: A climate reconstruction of Sydney Cove, New South Wales, using weather journal and documentary data, 1788-1791. Aust. Meteor. Oceanogr. J., 58, 83-98. , P. Brohan, and R. Allan, 2010a: The weather of the First Fleet voyage to Botany Bay, 1787-1788. Weather, 65, 315-319, doi:10.1002/wea.608.

_ D. Darden, and C. Fenby, 2010b: The influence of climate on the first European settlement of Australia: A comparison of weather journals, documentary data and palaeoclimate records, 1788-1793. Environ. Hist., 15, 485-507, doi:10.1093/envhis/emq079.

Glaisher, J., 1849: On the reduction of the thermometrical observations made at the apartments of the Royal Society, from the years 1774 to 1781 and from the years 1787 to 1843 . Philos. Trans. Roy. Soc. London, 139, 307-318.

- 1850: Sequel to a paper on the reduction of the thermometrical observations made at the apartments of the Royal Society. Philos. Trans. Roy. Soc. London, 140, 569-607.

Golinski, J., 2007: British Weather and the Climate of Enlightenment. University of Chicago Press, 272 pp.

Goulburn, F., 1825: A meteorological diary for twelve months kept in the years 1821-2 at Sydney New South Wales. Geographical Memoirs on New South Wales by Various Hands Together with Other Papers on the Aborigines, the Geology, the Botany, the Timber, the Astronomy, and the Meteorology of New South Wales and Van Diemen's Land, B. Field, Ed., J. Murray, 385-397.

Green, D., J. Billy, and A. Tapim, A., 2010: Indigenous Australians' knowledge of weather and climate. Climate Change, 100, 337-354, doi:10.1007/s10584-010-9803-z.

Grove, R., 2005: Revolutionary weather: The climatic and economic crisis of $1788-1795$ and the discovery of El Niño. $A$ Change in the Weather: Climate and Culture in Australia, T. Sherratt, T. Griffiths and L. Robin, Eds., National Museum of Australia Press, 128-140.

Hadley, G., 1735: On the cause of the general trade winds. Philos. Trans. Roy. Soc. London, 39, 58-62.

Hamilton, C., 2010: Requiem for a Species: Why We Resist the Truth about Climate Change. Allen \& Unwin, $286 \mathrm{pp}$.

Home, R. W., and K. T. Livingston, 1994: Science and technology in the story of Australian federation: The case of meteorology, 1876-1908. Hist. Rec. Aust. Sci., 10, 109-127.

Howse, D., 1969: Captain Cook's marine timekeepers. Part I: The Kendall watches. The Clocks and Watches of Captain James Cook, 1769-1969, D. Howse and B. Hutchinson, Eds., Thanet, 190-205.

Hulme, M., 2011: Meet the humanities. Nature Climate Change, 1, $177-179$.

Hutchins, T., 1783: Experiments for ascertaining the point of mercurial congelation. Philos. Trans. Roy. Soc. London, 73, 303-370. 
Jevons, W. S., 1859a: Some data concerning the climate of Australia and New Zealand. Waugh's Australian Almanac for the Year 1859, J. W. Waugh, Ed., 47-98.

— 1859b: Meteorological observations in Australia, being a continuation of those published in Waugh's Australian Almanac for 1858. Syd. Mag. Sci. Art, 2, 161-167.

_ 1859c: Meteorological observations in Australia. Syd. Mag. Sci. Art, 2, 173-181.

Jones, P. A., and A. Henderson-Sellers, 1992: Historical records of cloudiness and sunshine in Australia. J. Climate, 5, 260-267.

Jones, P. D., T. J. Osborn, and K. R. Briffa, 2001: The evolution of climate over the last millennium. Science, 292, 662-667.

King, P. P., 1825: On the maritime geography of Australia. Geographical memoirs on New South Wales by various hands together with other papers on the aborigines, the geology, the botany, the timber, the astronomy, and the meteorology of New South Wales and Van Diemen's Land, B. Field, Ed., J. Murray, 269-296.

Kington, J. A., 1997: The voyage of the British First Fleet from Portsmouth to Port Jackson in 1787-88 and its impact on the history of meteorology in Australia. Colonial Observatories and Observations: Meteorology and Geophysics, J. M. Kenworthy and J. M. Walker, Eds., Occ. Publ. 21, Department of Geography, University of Durham, 37-48.

Lamb, H. H., 1995: Climate, History and the Modern World. 2nd ed. Routledge, $464 \mathrm{pp}$.

Laurie, P. S., 1988: William Dawes and Australia's first observatory. Quart. J. Roy. Astron. Soc., 29, 469-482.

Loewe, F., 1965: The first Australian "Government Meteorologist." Aust. Meteor. Mag., 48, 46-48.

— 1970: The first series of meteorological observations in Australia. Aust. Meteor. Mag., 18, 39-41.

Manley, G., 1953: Mean temperature of central England, 16981952. Quart. J. Roy. Meteor. Soc., 79, 242-261.

_ 1974: Central England temperatures: Monthly means 1659 to 1973. Quart. J. Roy. Meteor. Soc., 100, 389-405.

McAfee, R. J., 1981: Dawes's Meteorological Journal. Bureau of Meteorology Historical Note 2 (with microfiche), Australian Government Publishing Service, 29 pp.

McConnell, A., 1992: Instrument Makers to the World: A History of Cooke, Troughton and Simms. William Sessions, 128 pp.

- 2005: Origins of the marine barometer. Ann. Sci., 62, 83-101.

McGuffie, K., and A. Henderson-Sellers, 2005: A Climate Modelling Primer. 3rd ed. Wiley, 296 pp.

Middleton, W. E. K., 1964: The History of the Barometer. Johns Hopkins Press, 489 pp.

- 1966: A History of the Thermometer and its Use in Meteorology. Johns Hopkins Press, 249 pp.

Morrison, D., and I. Barko, 2009: Dagelet and Dawes: Their meeting, their instruments and the first scientific experiments on Australian soil. Hist. Rec. Aust. Sci., 20, 1-40.

Nicholls, N., 1988: More on early ENSOs: Evidence from Australian documentary sources. Bull. Amer. Meteor. Soc., 69, 4-6.

_ 1998: William Stanley Jevons and the climate of Australia. Aust. Meteor. Mag., 47, 285-293.

Parker, D. E., and E. B. Horton, 2005: Uncertainties in central England temperature since 1878 and some changes to the maximum and minimum series. Int. J. Climatol., 25, 1173-1188.

Pidgeon, N., and B. Fischhoff, 2011: The role of social and decision sciences in communicating uncertain climate risks. Nat. Climate Change, 1, 35-41, doi:10.1038/nclimate1080.

Phelan, L., A. Henderson-Sellers, and R. Taplin, 2012: The political economy of addressing climate crisis in the Earth system:
Undermining perverse resilience. New Polit. Econ., doi:10.1080/ 13563467.2012.678820, in press.

Phillip, A., 1789 (cited 2011): The voyage of Governor Phillip to Botany Bay with an account of the establishment of the colonies of Port Jackson and Norfolk Island. [Available online at http:// www.gutenberg.org/files/15100/15100-h/15100-h.htm.]

Roebuck, J., 1775: A comparison of the heat of London and Edinburgh. Philos. Trans., 65, 459-462.

Roxburgh, W., and J. Pringle, 1778: A meteorological diary, \&c. kept at Fort St. George in the East Indies, by Mr. William Roxburgh, assistant-surgeon to the hospital at the said fort, communicated by Sir John Pringle, Bart. Philos. Trans. Roy. Soc. London, 68, 180-193.

Russell, H. C., 1887: Climate of New South Wales, Government Printer, New South Wales, 189 pp.

, 1888: Astronomical and meteorological workers in New South Wales, 1778 to 1860. Reprint from Proceedings. Australasian Association for the Advancement of Science, $49 \mathrm{pp}$.

1896: Moving anticyclones in the Southern Hemisphere. Three Essays on Australian Weather, R. Abercromby, Ed., Frederick W. White, 1-15.

Schmidt, G., and E. Moyer, 2008: A new kind of scientist. Nat. Rep. Climate Change, 2, 102-103.

Six, J., 1794: The construction and use of a thermometer for shewing the extremes of temperature in the atmosphere, during the observers absence together with experiments on the variations of local heat; and other meteorological observations. Blake and Wilkie, 62 pp.

Turner, N. J., and H. Clifton, 2009: "It's so different today": Climate change and indigenous lifeways in British Columbia, Canada. Global Environ. Change, 19, 180-190.

Vinther, B. M., K. K. Andersen, P. D. Jones, K. R. Briffa, and J. Cappelen, 2006: Extending Greenland temperature records into the late eighteenth century. J. Geophys. Res., 111, D11105, doi:10.1029/2005JD006810.

Watson, F., 1914: Historical records of Australia Series 1: Governors' dispatches to and from England, 1788-1796. The Library Committee of the Commonwealth Parliament, Sydney, Australia, $822 \mathrm{pp}$.

Wedgwood, J., 1784: Description and use of a thermometer for measuring the higher degrees of heat from a red heat up to the strongest that vessels made of clay can support. Joseph Cooper, 26 pp.

Wheeler, D., and C. Wilkinson, 2004: From calm to storm: The origins of the Beaufort wind scale. Mar. Mirror, 90, 187-201. , R. Garcia-Herrera, C. W. Wilkinson, and C. Ward, 2010: Atmospheric circulation and storminess derived from Royal Navy logbooks: 1685 to 1750 . Climate Change, 101, 257-280, doi:10.1007/s10584-009-9732-x.

R. García-Herrera, J. M. Vaquero, M. Chenoweth, and C. Mock, 2009: Reconstructing the trajectory of the August 1680 hurricane from contemporary records. Bull. Amer. Meteor. Soc., 90, 971-978.

Wolfendale, A. W., 1997: Astronomers Royal and the overseas collection. Colonial Observatories and Observations: Meteorology and Geophysics, J. M. Kenworthy and J. M. Walker, Eds., Occ. Pub 21, Department of Geography, University of Durham, 17-20.

Worgan, G., 1788 (cited 2011): Journal of a First Fleet Surgeon. [Available online at http://gutenberg.net.au/ebooks04/0400181.txt.]

Wright, T., 1785: Speculum meteorum: or An essay towards establishing a true theory of the weather analogous to that of the tides. Wright MSS 15, Durham University Library. 
Copyright of Weather, Climate \& Society is the property of American Meteorological Society and its content may not be copied or emailed to multiple sites or posted to a listserv without the copyright holder's express written permission. However, users may print, download, or email articles for individual use. 